\title{
Sputtered Cathodes for Polymer Electrolyte Fuel Cells: Insights into Potentials, Challenges and Limitations
}

\author{
Bernhard Schwanitz ${ }^{a}$, Annett Rabis ${ }^{a}$, Michael Horisberger ${ }^{b}$, Günther G. Scherer ${ }^{a}$, \\ and Thomas J. Schmidt*a
}

\begin{abstract}
The level of Pt loadings in polymer electrolyte fuel cells (PEFC) is still one of the main hindrances for implementation of PEFCs into the market. Therefore, new catalyst and electrode preparation methods such as sputtering are of current interest, because they allow thin film production and have many cost saving advantages for electrode preparation. This paper summarises some of the most important studies done for sputtered PEFCs, including non carbon supported electrodes. Furthermore, it will be shown that an understanding of the main morphological differences between sputtered and ink-based electrodes is crucial for a better understanding of the resulting fuel cell performance. Especially, the electrochemical surface area (ECSA) plays a key role for a further increase in PEFC performance of sputtered electrodes. The higher surface specific activities $i_{k, \text { spec }}$ of sputtered compared to ink-based electrodes will be discussed as advantage of the thin film formation. The socalled particle size effect, known in literature for several years, will be discussed as reason for the higher $i_{\mathrm{k}, \mathrm{spec}}$ of sputtered electrodes. Therefore, a model system on a rotating disc electrode (RDE) was studied. For sputtered PEFC cathodes Pt loadings were lowered to $100 \mu \mathrm{g}_{\mathrm{p}} / \mathrm{cm}^{2}$, yet with severe performance losses compared to ink-based electrodes. Still, for Pt sputtered electrodes on a carbon support structure remarkably high current densities of $0.46 \mathrm{~A} / \mathrm{cm}^{2}$ at $0.6 \mathrm{~V}$ could be achieved.
\end{abstract}

Keywords: Electrocatalysis · Electrochemistry · Particle size effect · Polymer electrolyte fuel cell · Sputtering

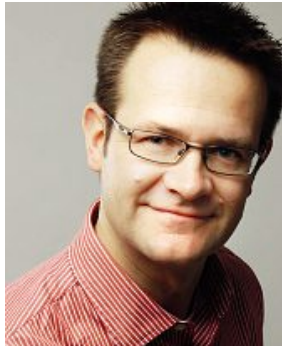

Thomas J. Schmidt received his University Diploma (1996) and his PhD (2000) in Chemistry from the University of Ulm (Germany), before he joined the group of P. N. Ross and N. M. Markovic at University of California Berkeley, Lawrence Berkeley National Laboratory. During this period, he intensively studied the fundamentals of electrocatalysis of fuel cell reactions. He continued to work with G. G. Scherer at Paul Scherrer
Institut in Villigen/Switzerland on the development of membrane electrode assemblies (MEAs) using radiation-grafted membranes and on oxygen electrocatalysis with oxide containing catalysts. From fall 2002, he worked in the industrial development of high-temperature membrane electrode assemblies and its components (membranes, catalysts, electrodes) using polybenzimidazole-based membranes at BASF Fuel Cell GmbH (formerly Pemeas $\mathrm{GmbH})$. During these eight years in industry, Dr. Schmidt led the high-temperature MEA R\&D activities as Director R\&D and helped to successfully commercialize the BASF Fuel Cell Celtec ${ }^{\circledR}$ MEAs. In parallel in 2009 and 2010, he worked as lecturer for Physical Chemistry at Provadis School of International Management and Technology, University of Applied Sciences in Frankfurt/Germany.

In February 2011, Dr. Schmidt was appointed Full Professor for Electrochemistry at the Swiss Federal Institute of Technology in Zurich (ETH Zürich) and as of January 2012, head of the Electrochemistry Laboratory in the General Energy Department at Paul Scherrer Institut, Villigen.

Dr. Schmidt has co-authored more than 40 peer-reviewed publications, eleven peer-reviewed book chapters and he is the inventor on 20 patent applications. He recently served as co-editor of the book entitled 'Polymer Electrolyte Fuel Cell Durability' (Springer). Dr. Schmidt is the 2010 recipient of the ECS Charles W. Tobias Young Investigator Award.

\section{Introduction}

Polymer electrolyte fuel cells (PEFC) are a promising technology for use in the automobile industry, which is at the frontier between R\&D and technological readiness. Although many breakthroughs with respect to component performance and durability, e.g. membrane electrode assemblies (MEA), electrodes, electrocatalysts, membranes etc., have been demonstrated, there are still open challenges to face before the technology and the devices will be penetrating the general automotive market. One of the main drawbacks is the need of the noble metal Pt as a catalyst in PEFCs, implying the correlation of the precious metal to the fuel cell cost, respectively. A 2008 study performed within the US Department of Energy's (DOE) Hydrogen and Fuel Cell Program showed that almost $50 \%$ of the total PEFC stack cost $\left(80 \mathrm{~kW}_{\text {net }}\right.$ fuel cell system) is due to the catalyst layer, assuming a mass production of 500,000 units per year and state of the art materials. ${ }^{[1]}$ Due to significant catalyst improvements (i.e. reduction of precious metal loadings for the same sized system) this 
share could be reduced to approximately $30 \%$ (assuming a $\mathrm{Pt}$ price of $c a .35 \$ / \mathrm{g}$ ) in the 2011 study under otherwise identical conditions. ${ }^{[2]}$ Despite these apparent improvements, a reduction of the Pt catalyst loading in PEFCs electrodes without a loss in performance is a comprehensive need for its application in the automobile industry.

In state of the art PEFCs, the Pt loading for the anode and the cathodes is in the range between 50-100 $\mu_{\mathrm{P}_{\mathrm{I}}} / \mathrm{cm}^{2[3-5]}$ and $200-500 \mu \mathrm{g}_{\mathrm{Pl}} / \mathrm{cm}^{2},{ }^{[5]}$ respectively. Whereas the reduction of $\mathrm{Pt}$ loading is straightforward for PEFC anodes, due to the fast reaction kinetics of the hydrogen oxidation reaction (HOR), ${ }^{[6-8]}$ the lowering of the Pt loading for the cathode is limited due to the sluggish oxygen reduction reaction (ORR) kinetics. ${ }^{[9]}$ Therefore, most effort is put into increasing the activity of $\mathrm{Pt}$ for the ORR, see e.g., refs. $[10,11]$ and references therein. Even with optimized catalyst layer designs, a reduction of the Pt loading will still result in the predictable kinetically determined voltage losses (i.e. $20 \mathrm{mV}$ for a Pt loading reduction by a factor of two). [5] The strategic goal for automotive industry is still best summarized in the work by Gasteiger et al., ${ }^{[5]}$ deriving an increase of the MEA power density up to $0.8-0.9 \mathrm{~W} /$ $\mathrm{cm}^{2}$ and a decrease of the Pt loading down to $0.2 \mathrm{~g}_{\mathrm{pt}} / \mathrm{kW}$ at $\geq 0.65 \mathrm{~V}$, respectively.

Most commonly PEFC fuel cell electrodes or catalyst layers in catalyst-coated membranes (CCM) are prepared by application of inks or pastes, containing $\mathrm{Pt} / \mathrm{C}$, ionomer, and a solvent (alcohol/water) onto gas diffusion media or solid polymer electrolytes. ${ }^{[3,12-14]}$ The layer thicknesses are usually $\geq 10 \mu \mathrm{m} .{ }^{[3,12,13]}$ Other methods for PEFC electrode preparation include for example electrodeposition of $\mathrm{Pt},{ }^{[15-17]}$ dual ion-beam assisted deposition, ${ }^{[18-20]}$ electroless deposition ${ }^{[21]}$ and sputter deposition. ${ }^{[22-46]}$ Especially, sputtering of PEFC electrodes seems attractive, because it is a dry process where the Pt loading is easily adjusted by the sputter parameters (time, power etc.). Using multiple sputtering targets, mixed metal catalyst layers are available in simultaneous co-sputtering, e.g. Pt and Co. Furthermore, very thin catalyst layers $(<1 \mu \mathrm{m})$ can be achieved, which may improve the mass transport properties of the electrodes, ${ }^{[47,48]}$ and thus, limit the loading-induced voltage losses to the kinetically predicted ones. Ultrathin catalyst layers will potentially also minimize Ohmic resistance losses in the catalyst layers. Another advantage is the possibility to sputter on carbon-free support structures ${ }^{[49]}$ which is beneficial, as carbon corrosion from the usual catalyst supports is one of the main causes of PEFC degradation. ${ }^{[50-53]}$ Using ultra-thin catalyst layers may also open possibilities to avoid ionomer, due to direct contact of the electrochemical active phase with the polymer electrolyte membrane; for a discussion of this effect we refer to ref. [54].

In this work, we examined sputtered PEFC cathodes with various $\mathrm{Pt}$ loadings between 5 and $500 \mu \mathrm{g}_{\mathrm{pt}} / \mathrm{cm}^{2}$. We compare the properties of the in-house prepared sputtered electrodes to commercially available electrodes based on ink fabrication and to properties of similar systems described in the literature. We show the main morphological differences between the different types of electrodes and derive possible reasons for the differences in fuel cell performance. For a better theoretical understanding of these differences, model electrodes have been prepared and were investigated in liquid electrolyte by rotating disk electrode (RDE) measurements. This allows a better experimental control of the electrode properties and therefore more precise kinetic measurements. Electrochemical impedance spectroscopy was employed in our PEFC measurements to analyze the electrodes inside MEAs and obtain the Ohmic cell resistance. The morphology of the sputtered Pt layers was investigated by transmission electron microscopy.

\section{Experimental}

\subsection{Preparation and Characterization of Sputtered Model Electrodes}

The preparation of the model electrodes can be divided into two parts. At first, a Vulcan suspension is mixed from $75 \mathrm{mg}$ of Vulcan XC72 with $100 \mu$ l of Nafion ${ }^{\circledR} 117$ solution (5\%, Fluka) and $25 \mathrm{~mL}$ 2-propanol (Normapur, VWR Prolabo). The suspension was treated ultrasonically at $60^{\circ} \mathrm{C}$ for $10 \mathrm{~min}$, and then was stirred for $10 \mathrm{~min}$ at $40{ }^{\circ} \mathrm{C}$. This procedure was repeated in the following sequence: $10 \mathrm{~min}$ ultrasonic bath, $10 \mathrm{~min}$ stirring, $120 \mathrm{~min}$ ultrasonic bath, 10 min stirring and 180 min ultrasonic bath. Then $20 \mu \mathrm{l}$ of the suspension were dispersed onto a polished glassy carbon rotating disk electrode (RDE), and dried overnight at room temperature in an Ar atmosphere. Since the prepared carbon thin film support is acting as a model micro-porous layer (MPL) as used in the fuel cell gas diffusion electrodes (see below), we ensured that the glassy carbon electrode is covered by a complete dense and homogeneous Vulcan XC72 carbon thin film by verification under an optical microscope. In the second part of the electrode preparation different $\mathrm{Pt}$ loadings 2, 10, 20,100 and $500 \mu \mathrm{g}_{\mathrm{P}_{\mathrm{t}}} / \mathrm{cm}^{2}$, were sputtered onto the electrodes in a magnetron sputtering set-up ('TIPSI' at the PSI Laboratory of Developments and Methods). Argon was utilized as sputter gas at a pressure of $10^{-3}$ mbar and a sputtering power of 50 W. Rutherford Back Scattering (RBS) spectroscopy was used to determine the $\mathrm{Pt}$ loading, as described elsewhere. ${ }^{[55]}$

For each Pt loading all five electrodes were characterized in a three electrode compartment electrochemical cell in $0.1 \mathrm{M} \mathrm{HClO}_{4}$ (SupraPure ${ }^{\circledR} 70 \%$, Merck) using a Pt-mesh as counter electrode. All potentials were measured vs. a saturated $\mathrm{Ag} / \mathrm{AgCl}$ reference electrode separated by an electrolyte bridge from the working electrode compartment. All potentials are referred to the reversible hydrogen electrode (RHE) calibrated by hydrogen oxidation/evolution reaction in the same electrolyte. Owing to slight contaminations, e.g. from the Nafion ${ }^{\circledR}$ in the Vulcan suspension, the electrode potential was cycled several times between 0.05 and $1.2 \mathrm{~V}$ (RHE) in order to produce a clean surface. The electrochemical surface area (ECSA) was determined by integration of the $\mathrm{H}_{\text {upd }}$ region in Ar saturated electrolyte via cyclic voltammetry (CV) (normalization factor of $\left.0.210 \mathrm{mC} / \mathrm{cm}^{2}\right)$. Finally, the ORR was measured in an $\mathrm{O}_{2}$ saturated electrolyte at different rotation rates, and the resulting polarization curves were iR corrected. Each measurement was recorded at ambient temperature and pressure. Unless specifically denoted, the sweep rate was $5 \mathrm{mV} / \mathrm{s}$. For the kinetic analysis, the cathodic sweeps have been used after holding the electrode potential for $10 \mathrm{~s}$ at $1.2 \mathrm{~V}$.

\subsection{Preparation and Characterization of Sputtered Pt Cathodes for the PEFC}

Varying amounts of Pt were sputtered onto carbon cloth (BASF Fuel Cell, type LT1410W), covered with a microporous carbon layer (MPL), using the aforementioned sputtering set-up and parameters. The sputtered cathodes were hot pressed (3 min, $120{ }^{\circ} \mathrm{C}, 30 \mathrm{Nm}^{-2}$ ) with dry Nafion 212 and commercial anodes (BASF Fuel Cell, type LT140EWSI, $500 \mu \mathrm{g}_{\mathrm{P}} / \mathrm{cm}^{2}$ ), to yield the membrane electrode assemblies (MEAs). ${ }^{[6]}$ For comparison of the sputtered cathodes with a commercial ink-based cathode, a reference MEA, containing the same commercial electrode as cathode, was hot pressed in the same manner. Note that the catalyst layers of the commercial electrodes contain ionomer, whereas the sputtered catalyst layers did not. The geometrical surface area of the MEAs is 29.3 $\mathrm{cm}^{2}$. MEAs with sputtered cathode loadings of $5,25,50,100$ and $500 \mu \mathrm{g}_{\mathrm{pt}} / \mathrm{cm}^{2}$ are denoted as MEA5, MEA25, MEA50, MEA100 and MEA500, the reference MEA as MEA-ETEK throughout the text.

For fuel cell testing, the MEAs were conditioned in a PEFC for at least $20 \mathrm{~h}$ at $0.1 \mathrm{~A} / \mathrm{cm}^{2}, 80{ }^{\circ} \mathrm{C}, 1$ bar, $\mathrm{H}_{2} / \mathrm{O}_{2}$ stoichi- 
ometry of $6 / 12$ and $100 \%$ relative humidity (R.H.). Hydrogen (N4.5) and oxygen (N4.5) supplied by Messer-Griesheim were used as reactant gases. The ECSA inside the PEFCs was determined by COstripping, using a Zahner IM6 workstation at $80{ }^{\circ} \mathrm{C}, 1$ bar, $100 \% / 100 \%$ R.H., $\mathrm{H}_{2} / \mathrm{N}_{2}$ $=200 \mathrm{~mL} / 200 \mathrm{~mL}$ and $\mathrm{v}=10 \mathrm{mV} / \mathrm{s}$ in the cell voltage region of $0.08-1 \mathrm{~V}$. Currentvoltage curves were taken at the same fuel cell conditions, as described for break-in. For the iR correction, electrochemical impedance spectra were recorded with a Zahner IM6 workstation simultaneous to the polarization measurements, resulting in the Ohmic cell resistance value. [6]

Transmission electron microscopy (TEM) of the electrodes was carried out at a Phillips CM12 microscope operated at $120 \mathrm{kV}$. Samples of the above described MEAs, embedded in an epoxy resin (Araldite 502, Polysciences, Inc.), [56] were sectioned $(70 \mathrm{~nm})$ with a microtome. The sections were then transferred onto TEM grids (Plano $\mathrm{GmbH}$, type $\mathrm{S} 160$ ). The catalyst layer of the commercial electrode was scratched off from the gas diffusion layer by a scalpel and transferred onto TEM grids before the measurements.

\section{Results and Discussion}

\subsection{Morphological Comparison of Cathode Catalyst Layers}

For a deeper insight in the different catalyst layer (CL) properties of sputtered vs. catalyst ink-based CL the understanding of their morphologies is quite crucial. Therefore, TEM pictures of pristine catalyst layers are shown in Fig. 1. The Pt particles are highly dispersed in the case of the ink-based electrodes (Fig. 1a) due to the formation of a homogeneous mixture of $\mathrm{Pt}$ on carbon already during the catalyst synthesis. Since the high Pt dispersion on the carbon support is already formed during synthesis, the amount of Pt in the catalyst layer can be varied only as a function of the CL thickness or in the catalyst preparation step by the Pt loading on the carbon support. Typical CL thicknesses are around $10 \mu \mathrm{m}$ to $50 \mu \mathrm{m} .{ }^{[47,48,57,58]}$

The dispersion of sputtered $\mathrm{Pt}$ on the MPL of the Gas Diffusion Electrode (GDE) on the other hand is dependent on its Pt loading. ${ }^{[5]}$ For low Pt loadings $\left(3 \mu \mathrm{g}_{\mathrm{pt}} / \mathrm{cm}^{2}\right) \mathrm{Pt}$ nanoparticles $(\mathrm{d} \approx 2 \mathrm{~nm})$ are highly dispersed on the carbon support material. With increasing Pt loading agglomerates and even films are formed, leading to a significant lowering of the $\mathrm{Pt}$ dispersion. This process starts already for loading values of $25 \mu \mathrm{g}_{\mathrm{Pt}} / \mathrm{cm}^{2}$ (Fig. 1b). The reason for agglomeration, already at these low loadings, is the low sputtering depth into the MPL. As demonstrated by
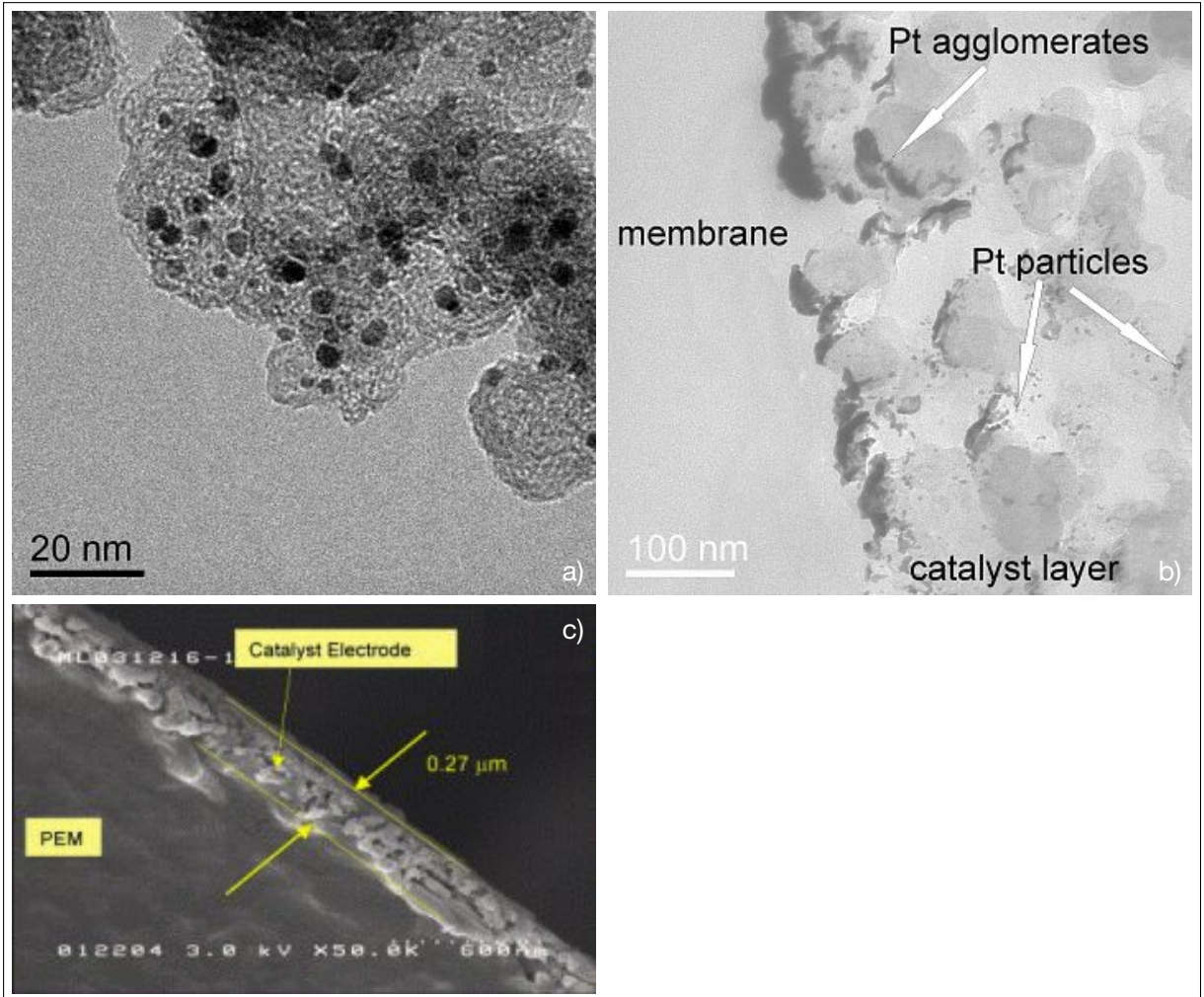

Fig. 1. TEM images at various resolutions of polymer electrolyte fuel cell (PEFC) electrodes, prepared by a) casting an ink solution of binder/ionomer and $\mathrm{Pt} / \mathrm{C}$; b) sputtering of $\mathrm{Pt}$ on a microporous layer (MPL) of carbon, $25 \mu \mathrm{g}_{\mathrm{Pt}} / \mathrm{cm}^{2}$; and c) sputtering of Pt on a thin film nanostructure (NSTF) and transferring it to a polymer electrolyte membrane. Fig. 1a reprinted from Electrocatalysis 2, B. Schwanitz, H. Schulenburg, M. Horisberger, A. Wokaun, G. G. Scherer, 'Stability of Ultra-low Pt Anodes for Polymer Electrolyte Fuel Cells Prepared by Magnetron Sputtering', 35-41, copyright 2011 with permission from Springer. Fig. 1c reprinted from J. Power Sources 161, M. K. Debe, A. K. Schmoeckel, G. D. Vernstrorn, R. Atanasoski, 'High voltage stability of nanostructured thin film catalysts for PEM fuel cells', 1002-1011, copyright 2006 with permission from Elsevier. our TEM analysis in combination with RBS measurements, ${ }^{[55]}$ within our range of Pt loadings ( 3 to $500 \mu \mathrm{g}_{\mathrm{Pt}} / \mathrm{cm}^{2}$ ) most Pt is deposited within a layer thickness $<1 \mu \mathrm{m}$ on top of the underlying porous carbon layer.

For comparison, in Fig. 1c an SEM image of a nano-structured thin film (NSTF)

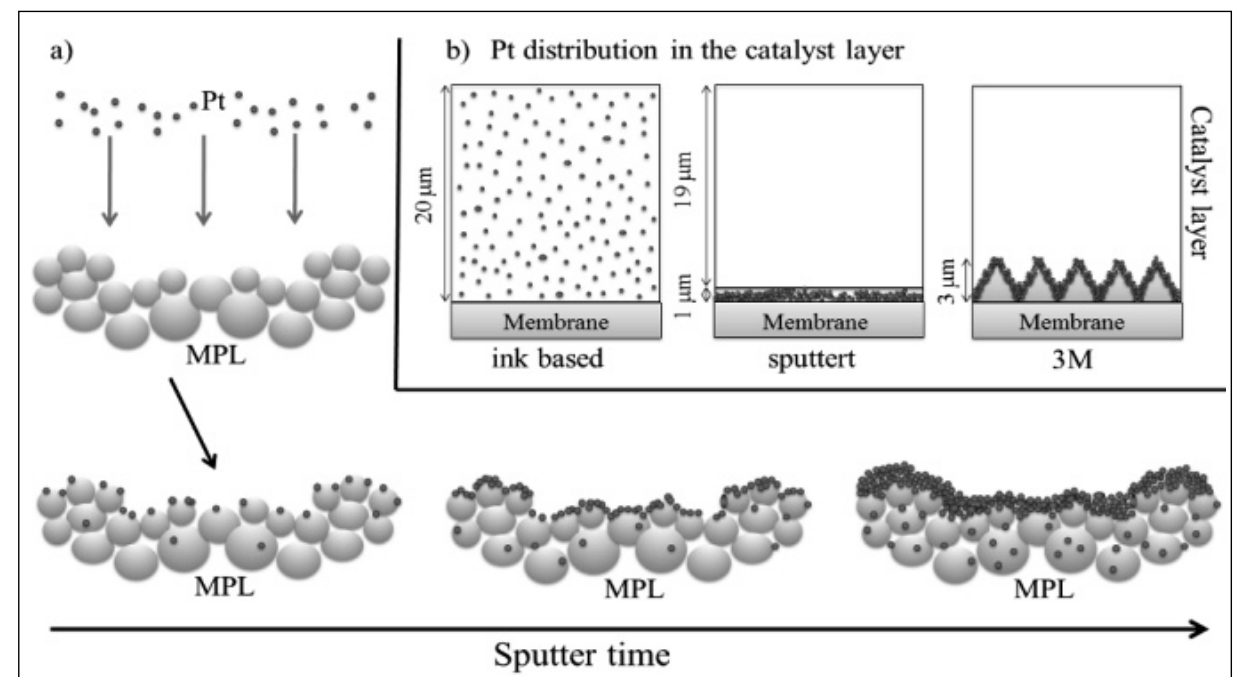

Fig. 2. a) Scheme of the Pt sputtering process on a MPL with increasing sputter time. For clarity, the gas diffusion layer (GDL) is not displayed. b) Pt distribution in the catalyst layer of an inkbased, a sputtered, and a $3 \mathrm{M}$ electrode. The latter scheme is presented as a virtual cross section showing, from bottom to top, the membrane and the catalyst layer. After the Pt catalyst layer follows the MPL for the sputtered, and the GDL for the 3M electrode. In these examples, the application of the catalyst layers (both ink based and sputtered) occurs on the electrode rather than on the membrane side. 
catalyst layer ${ }^{[4]}$ is shown. Clearly, the thin catalyst layer with a thickness of less than $0.3 \mu \mathrm{m}$ can be observed, alongside with the still relatively porous high surface area resulting from the whisker-type substrate, see e.g. Fig. 1 in ref. [4] or Fig. 2 in ref. [59].

A scheme of the catalyst layer preparation process by sputtering is given in Fig. $2 \mathrm{a}$, together with a sketch of a virtual cross section of the catalyst layer of the sputtered and ink-based electrodes (Fig. 2b). Pt particles are represented as the dark round particles. The scheme shows that the same amount of $\mathrm{Pt}$ is distributed in significantly thicker catalyst layers when using catalyst ink preparation, with a carbon supported catalysts, as compared to the sputter preparation. This in turn leads to much higher $\mathrm{Pt}$ dispersion inside the catalyst layer, when supported catalysts are used. Note that the CL thickness, using supported catalysts, can basically only be influenced by the metal loading on the support. The morphology has a direct influence on ECSA, as will be shown in the next section. The sketch for the 3M nano-structured thin-film catalysts (NSTF) ${ }^{[4]}$ is drawn for comparison (Fig. 2). Here, $\mathrm{Pt}$ or Pt-alloys are sputtered onto the surface of organic whiskers with $\sim 0.5 \mu \mathrm{m}$ length. The Pt sputtered whiskers are transferred from the substrate to the polymer electrolyte by a hot pressing step similar to the well-known decal process ${ }^{[14]}$ creating a 'zig-zag' textured surface with $\sim 6 \mu \mathrm{m}$ pitch-to-pitch distance and $90^{\circ}$ angle in order to increase the Pt utilization, ${ }^{[60]}$ i.e. the surface area exposed to the electrolyte. As will be shown later, the sputtered Pt catalyst layers behave like 'advanced' Pt-black rather than a $\mathrm{C}$-supported $\mathrm{Pt}$ catalyst.

\subsection{ECSA of Sputtered Electrodes}

The morphology of the catalyst layer and in particular the Pt dispersion on the support has a direct influence on ECSA. An ideal homogeneous dispersed system, like an ink-based catalyst layer, shows a linear increase of ECSA with increasing Pt loading under the assumption of constant catalyst utilization of $100 \%$, which is displayed on the logarithmic scale in Fig. 3. This conclusion is trivial, because the amount of highly dispersed Pt nanoparticles (no agglomeration assumed) increases with increasing Pt loading. For the low dispersed sputtered catalyst layers in our GDEs we found a logarithmic growth of the electrochemical active surface area. A similar correlation was observed for the catalytic active area of our sputtered model electrodes. Data in Fig. 3 are depicted from $\mathrm{H}_{\text {upd }}$ and CO-stripping results from model electrodes and fuel cell cathodes, respectively. The reason for this non-linear correlation can be found in the agglomeration of the individual Pt nanoparticles. Due to

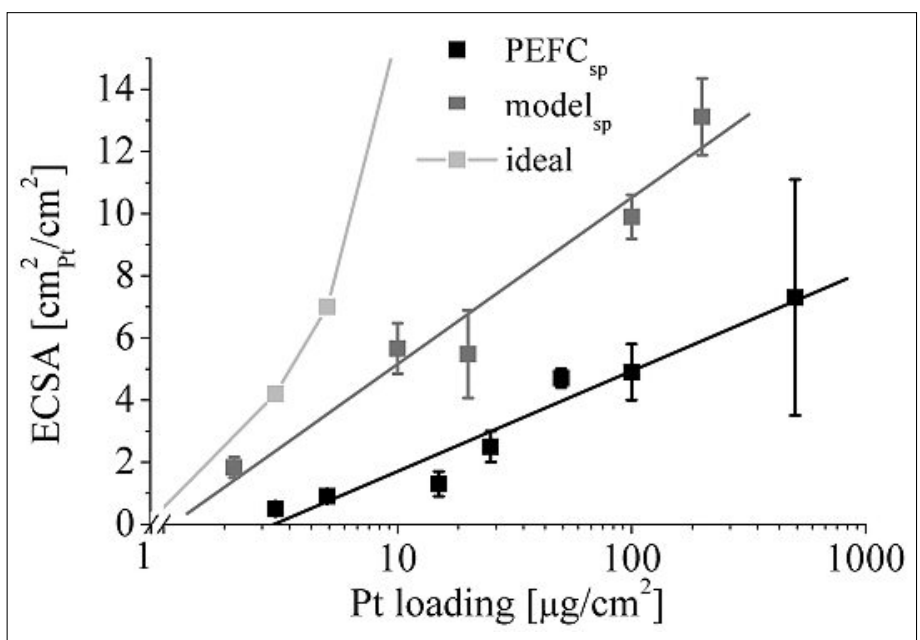

Fig. 3. Plot of ECSA vs. the Pt loading shown for the sputtered model, sputtered PEFC and virtually for a linear growth of an ideal ink-based electrodes. Surface areas were measured by $\mathrm{H}_{\text {UPD }}$ for the sputtered model and by $\mathrm{CO}$-stripping for the sputtered PEFC electrode.

the occurrence of agglomeration catalytic active surface area is lost, which is leading to significant deviations of the catalyst utilization.

ECSA for the model electrodes were determined using the integration of the $\mathrm{H}_{\text {UPD }}$ region from the cyclic voltammograms (shown in Fig. 4) after correction for the double layer charges. The values for the model electrodes are higher (Fig. 3 ) compared to the values obtained from GDEs inside a PEFC, most likely due to the better contact of the Pt surface to the liquid electrolyte as compared to the Nafion membrane surface. When fabricating electrodes with solid polymer electrolytes, it is not guaranteed that all of the $\mathrm{Pt}$ surface area of the catalyst is available for the electrochemical reaction, due to either insufficient contact with the solid polymer electrolyte or due to electrical isolation of catalyst particles from each other by a film of the electrically non-conducting solid electrolyte. ${ }^{[61]}$ For our in-house made MEAs with sputtered catalyst layers, only about $\mathrm{ca}$. 30 to $70 \%$ of the originally sputtered Pt layer is in contact with the Nafion membrane in the hot-pressed MEA. Please note that the GDEs do not contain any ionomer, i.e. the electrochemical contacting of the Pt layer is fully dependent on the proton diffusion on the extended Pt-blacktype surface. Indeed, careful analysis of the data in Fig. 3 show that the highest discrepancies occur at the low Pt loadings, pointing to the fact that due to the carbon MPL surface roughness some of the sputtered Pt particles are neither in direct contact to the membrane nor to another $\mathrm{Pt}$ particle, and hence, proton surface diffusion from the electrolyte to the Pt surface cannot take place. ${ }^{[54]}$

Care must be taken with the measured values of ECSA at Pt loadings $\leq 10 \mu \mathrm{g}_{\mathrm{Pt}} /$ $\mathrm{cm}^{2}$. For those low loadings the double layer correction of the $\mathrm{H}_{\mathrm{UPD}}$ charge leads to rather big errors in the calculation of the ECSA. At these low Pt loadings, the total charge under the $\mathrm{CV}$ is dominated by the double layer charging of the carbon substrate, and not by the Pt pseudocapacitance. As a consequence, the double layer charging current is approximately 10 times higher than the pseudo-capacitive current from the $\mathrm{H}_{\mathrm{UPD}}$. Thus, an error of $10 \%$ in the determination of the double layer current leads to an error of $100 \%$ for the $\mathrm{H}_{\mathrm{UPD}}$ current. Hence, the error bar for determination of the catalytic active area for the 2 and $10 \mu \mathrm{g}_{\mathrm{pt}} / \mathrm{cm}^{2}$ electrodes is in the order of $100 \%$. In order to minimize this effect, the $\mathrm{CV}$ s of pure carbon MPL electrodes were

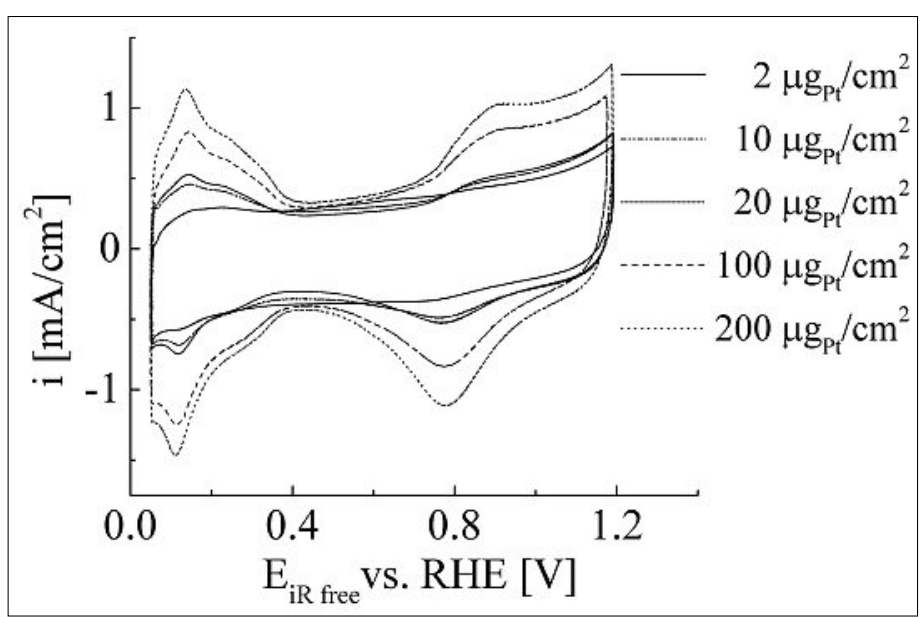

Fig. 4. Cyclic voltammetry curves for sputtered model electrodes with $\mathrm{Pt}$ loadings from 2 to $200 \mu \mathrm{g}_{\mathrm{pt}} / \mathrm{cm}^{2}$ in Ar saturated $0.1 \mathrm{M} \mathrm{HClO}_{4}$ solution. Sweep rate $50 \mathrm{mV} / \mathrm{s}$ at room temperature and ambient pressure. 
subtracted from the $\mathrm{Pt} / \mathrm{C}$ electrode $\mathrm{CV}$ prior to the integration of the $\mathrm{H}_{\mathrm{UPD}}$ charge. It should be noted, however, that also this method implies an error, since some of the carbon surface is indeed covered by $\mathrm{Pt}$ even at low loadings, therefore the double layer capacitance of the carbon surface exposed to the electrolyte is slightly overestimated by approx. 7\% (estimated from the maximum theoretical area covered by $2 \mathrm{~nm}$ particles), leading to smaller charges and, hence, to a slight underestimation of the active Pt surface area. Despite this error, the latter described method proved to be the most reliable one for these specific electrodes.

A comparison of the surface area of different model and fuel cell GD electrodes, respectively, is given in Table 1 . The ECSA of the sputtered fuel cell and the ink-based electrodes, respectively, with a Pt loading of $500 \mu \mathrm{g}_{\mathrm{pt}} / \mathrm{cm}^{2}$ show values of 7.3 and $110 \mathrm{~cm}_{\mathrm{Pt}}^{2} / \mathrm{cm}^{2}$, respectively, i.e. only about $7 \%$ of ECSA of the ink-based electrode. One way to increase the dispersion of $\mathrm{Pt}$ in sputtered electrodes is to increase the surface area of the substrate material, which was achieved by the $3 \mathrm{M}^{[4,59,62]}$ preparation technique, using three-dimensionally structured whiskers as substrates and textured catalyst layer transfer onto the membrane. The NSTF electrodes have active surface areas of about $10 \mathrm{~cm}_{\mathrm{pt}}{ }^{2} / \mathrm{cm}^{2}$ in comparison to our fuel cell MEAs with an ECSA of $4.9 \mathrm{~cm}_{\mathrm{Pt}}^{2} / \mathrm{cm}^{2}$ for the same Pt loading of $100 \mu \mathrm{g}_{\mathrm{pt}} / \mathrm{cm}^{2}$. From the measured ECSAs and theoretical maximum ECSAs at $100 \%$ utilization, calculated under the assumption of no Pt particle agglomeration and complete Pt surface area availability, we determined the real Pt utilization. The real utilization of the sputtered model and fuel cell electrodes is relatively low (7 and 4\%, respectively). As discussed before, not all of the Pt surface area is available for electrocatalysis due to insufficient contact between $\mathrm{Pt}$ and ionomer/membrane and due to agglomeration of Pt particles. Sputtered model electrodes with a Pt loading of only
$2 \mu \mathrm{g}_{\mathrm{P}_{\mathrm{t}}} / \mathrm{cm}^{2}$ have a utilization of about $50 \%$. The determined Pt utilization of the NSTF supported $\mathrm{Pt} / \mathrm{C}$ electrodes is about $43 \%$ for a Pt loading of $100 \mu \mathrm{g}_{\mathrm{P}} / \mathrm{cm}^{2}$ compared to the $7 \%$ for the model electrode with a slightly higher Pt loading.

\subsection{Electrocatalytic Activity of Model Electrodes}

For a better and more precise understanding of the ORR kinetics of the sputtered fuel cell electrodes, RDE measurements on the model electrodes have been conducted in order to determine pure kinetic current densities $\left(i_{\mathrm{k}}\right)$ in the absence of mass-transport limitation. ${ }^{[63-65]}$

The RDE ORR current densities were measured for various Pt loadings at different rotating speeds between 400 and $2500 \mathrm{rpm}$ at $20^{\circ} \mathrm{C}$. From these data, LevichKoutecky plots $\left(1 / i\right.$ vs. $\left.1 / \omega^{0.5}, \mathrm{i} @ 0.4 \mathrm{~V}_{\mathrm{RHE}}\right)$ were prepared for the different $\mathrm{Pt}$ loadings and Levich constants between $4.3-4.5^{*} 10^{-2}$ $\mathrm{mA}^{*} \mathrm{rpm}^{0.5}$ were determined, which are in good agreement to the theoretical value of $4.5 * 10^{-2} \mathrm{~mA}^{*} \mathrm{rpm}^{0.5}$ for a four electron process, following the well-known Levich equation: ${ }^{[66]}$

$$
i_{d}=0.620 n F D^{2 / 3} v^{-1 / 6} c_{0} \omega^{1 / 2}
$$

where $i_{\mathrm{d}}$ is the diffusion limited current density, $D$ is the oxygen diffusion coefficient in the electrolyte, $v$ is the kinematic viscosity, and $\omega$ is the rotation rate $\left(D=1.93 * 10^{-5} \mathrm{~cm}^{2} / \mathrm{s}, v=1.009 * 10^{-2} \mathrm{~cm}^{2} / \mathrm{s}\right.$ and $\left.c_{0}=1.26^{*} 10^{-3} \mathrm{~mol} / \mathrm{L}\right) .{ }^{[67]}$ In order to extract the true kinetic current densities $i_{\mathrm{k}}$ from the RDE curves, $i_{\mathrm{k}}$ was calculated using the following relation

$$
\frac{1}{i}=\frac{1}{i_{d}}+\frac{1}{i_{k}}=\frac{1}{B c_{0} \omega^{1 / 2}}+\frac{1}{i_{k}}
$$

where $i_{k}$ and $i_{d}$ represent the kinetically and diffusion-limited current densities, respectively.

The resulting Tafel plots are shown in
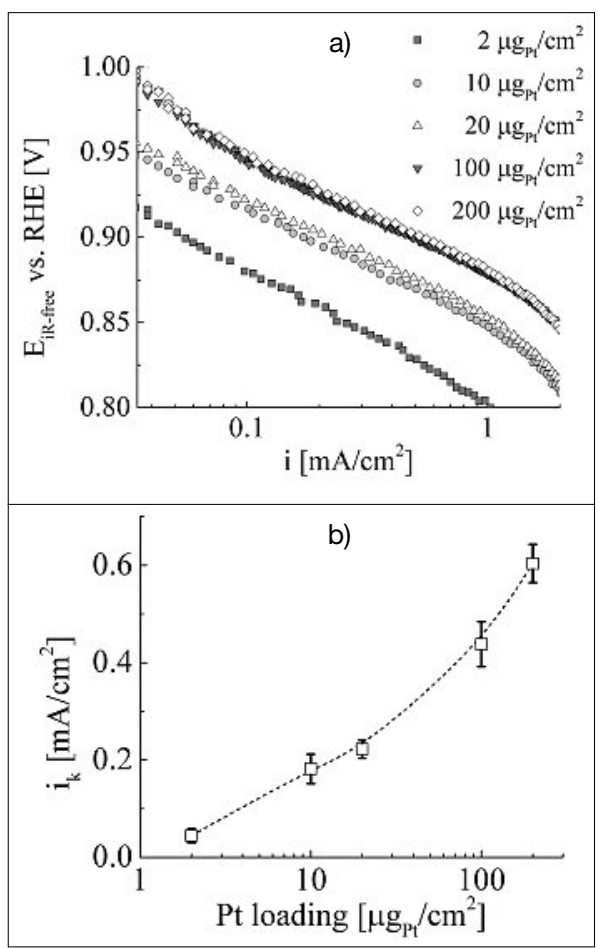

Fig. 5. a) Mass transport corrected current densities for the ORR on the sputtered Pt on Vulcan model MPL thin-film RDEs for different Pt loadings, obtained from cathodic sweeps $(5 \mathrm{mV} / \mathrm{s}, 1600 \mathrm{rpm})$ in $0.1 \mathrm{M} \mathrm{HClO}_{4}$ saturated with $\mathrm{O}_{2}$ at ambient temperature and pressure. b) Comparison of the $\mathrm{O}_{2}$ reduction activity of sputtered Pt/Vulcan model electrodes with different $\mathrm{Pt}$ loadings at ambient temperature and pressure, current densities are at constant electrode potential of $0.90 \mathrm{~V}(\mathrm{RHE})$. The dashed line serves as guide to the eye.

Fig. 5a, and the corresponding values for $i_{k}$ at $0.9 \mathrm{~V}$ in Fig. 5b. A logarithmic increase of $i_{\mathrm{k}}$ with Pt loading is observed, following the logarithmic increase of ECSA, shown in Fig. 3. The curves show Tafel slopes between -60 and $-62 \mathrm{mV} / \mathrm{dec}$, which are in good agreement, with slopes reported for Pt single crystals, ${ }^{[68]}$ polycrystalline $\mathrm{Pt},{ }^{[69]}$ Pt nanoparticles, ${ }^{[70]}$ thin films of $\mathrm{Pt}^{[64]}$ and Pt alloys ${ }^{[71,72]}$ on carbon support material, Pt in contact to the Nafion interface ${ }^{[73,74]}$

Table 1. Comparison of ECSA and Pt utilization for sputtered model electrodes, fuel cell MEA and NSTF supported Pt/C electrodes. Pt utilization was determined by calculating a theoretical maximum ECSA assuming the complete Pt surface area would be available. NSTF data taken from ref. [4] (+) and ref. [62] (*)

model electrode

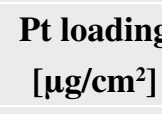

50

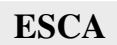

$$
\left[\mathrm{cm}^{2}{ }_{\mathrm{Pt}} / \mathrm{cm}^{2}\right]
$$

\section{Pt utilization} [\%]

]

fuel cell MEA

$\mathrm{ESCA}$
$\left.\mathrm{cm}_{\mathrm{Pt}}^{2} / \mathrm{cm}^{2}\right]$

4.7

4.9

Pt utilization
[\%]

7
NSTF

$\begin{array}{cc}\text { ESCA } & \text { Pt utilization } \\ {\left[\mathrm{cm}^{2}{ }_{\mathrm{Pt}} / \mathrm{cm}^{2}\right]} & {[\%]}\end{array}$



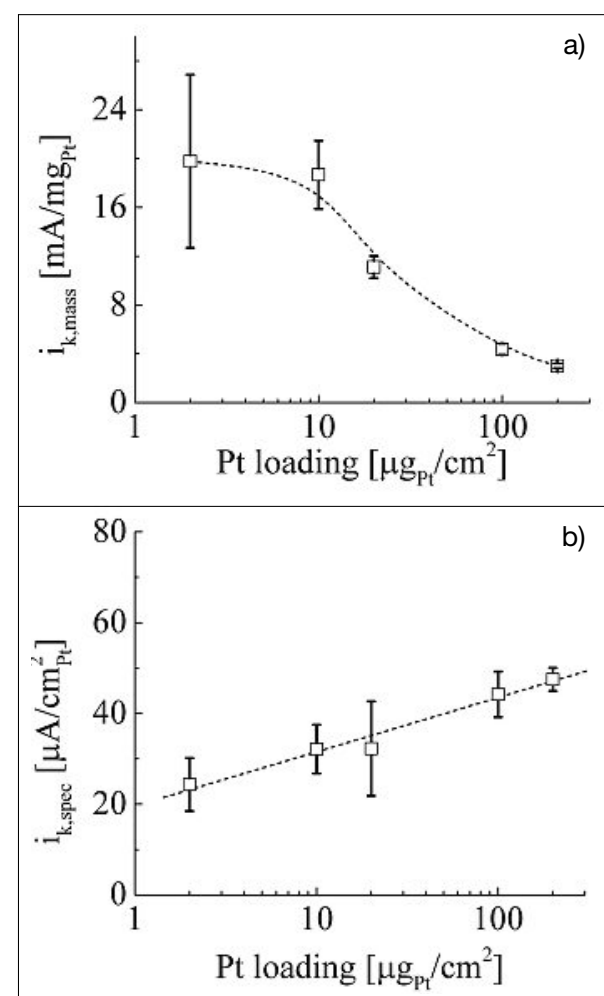

Fig. 6. Comparison of the $\mathrm{O}_{2}$ reduction a) mass specific activity $i_{k, \text { mass }}$ and $b$ ) surface specific activity $i_{\text {kspec }}$ of sputtered Pt on Vulcan layer model electrodes with different $\mathrm{Pt}$ loadings at ambient temperature and pressure, current densities are at constant electrode potential of $0.90 \mathrm{~V}(\mathrm{RHE})$. The lines serve as guide to the eye.

and Pt-based catalysts inside PEFCs ${ }^{[5]}$ with values around $-2.3 *(\mathrm{RT} / \mathrm{F})=-59 \mathrm{mV} / \mathrm{dec}$.

The mass-normalized current densities $\left(i_{\mathrm{k}, \text { mass }}\right)$ at $0.9 \mathrm{~V}$ are presented in Fig. 6a, alongside with the specific current densities $i_{\mathrm{k}, \mathrm{spec}}\left(i_{\mathrm{k}}\right.$ normalized to the specific surface area). The activity for $i_{\mathrm{k} \text {,mass }}$ for the $10 \mu \mathrm{g}_{\mathrm{pt}} / \mathrm{cm}^{2}$ sample of $c a .19 \mathrm{~mA} / \mathrm{mg}_{\mathrm{pt}}$ corresponds well to the typical values for $\mathrm{Pt} / \mathrm{Vulcan}$ catalysts reported in the literature, when the temperature effect is taken into account using the activation energy from ref. [64] $(25 \mathrm{~kJ} / \mathrm{mol}$, resulting in $\mathrm{ca}$. $120 \mathrm{~mA} / \mathrm{mg}_{\mathrm{Pt}}$ at $80{ }^{\circ} \mathrm{C}$ ), for comparison see Table 2 in ref. [5], and other typical values for carbon supported catalyst in the temperature range between 50 and $60{ }^{\circ} \mathrm{C}$ in refs $[64,70,75]$

As expected, the values for $i_{\mathrm{k}, \mathrm{mass}} \mathrm{de}-$ crease for increasing $\mathrm{Pt}$ loadings, also reflecting the decrease in specific surface area with increasing Pt loading. For ideally dispersed systems and $100 \%$ utilization, a linear correlation between $\mathrm{Pt}$ mass $\mathrm{m}_{\mathrm{Pt}}$, ECSA, and $i_{\mathrm{k}}$ is expected, assuming identical Pt nanoparticles, and therefore $i_{\mathrm{k} \text {,mass }}=$ $i_{\mathrm{k}} / \mathrm{m}_{\mathrm{Pt}}$ should stay the same. In reality, for perfectly dispersed systems, the catalyst utilization is typically decreasing with increasing Pt loading, as e.g. the sputtered $\mathrm{Pt}$ catalysts used in this study.
In Fig. $6 \mathrm{~b}$ the specific ORR activity $\left(i_{\mathrm{k}, \mathrm{spec}}\right)$ is plotted as a function of the $\mathrm{Pt}$ loading, using the values of the experimentally determined Pt surface area for calculation (see Fig. 3). Assuming identical reaction kinetics and Pt surface properties, respectively, $i_{\mathrm{k}, \mathrm{spec}}$ should stay identical independently of the Pt loading, e.g. also for relative low dispersed sputtered electrodes. However, Fig. $6 \mathrm{~b}$ clearly reveals a constant decrease in specific activity with decreasing Pt loading. This finding can be explained by a particle size effect ${ }^{[5,76]}$ in these electrodes, using sputtered Pt surfaces. Gasteiger et al. showed that $i_{\mathrm{k} \text {,spec }}$ is increasing with increasing Pt particle size, starting from Pt nanoparticles $(\mathrm{d}=2-6$ $\mathrm{nm})$, to Pt-black (d = 10-20 nm) and to a smooth Pt surface $(\mathrm{d}=$ several hundred nm). ${ }^{[5,77]}$ As described before, sputtered catalysts also show a change in morphology, starting from isolated $\mathrm{Pt}$ nanoparticles $(2-3 \mathrm{~nm})$ for loadings $\leq 20 \mu \mathrm{g}_{\mathrm{pt}} / \mathrm{cm}^{2}$ ending at $\mathrm{Pt}$ agglomerates up to particular films for loadings above $20 \mu \mathrm{g}_{\mathrm{Pt}} / \mathrm{cm}^{2}$. The limits, of course, are fluid, yet we propose the same particle size effect responsible for the increase of $i_{\mathrm{k}, \mathrm{spec}}$ at higher Pt loadings.

The change in specific activity with increasing particle size or decreasing specific surface area can be experimentally explained by a change in the $\mathrm{OH}_{\mathrm{ad}}$ adsorption properties by the $\mathrm{Pt}$ particle size. Gasteiger et al. ${ }^{[5]}$ showed that the adsorption potential for $\mathrm{Pt}$ particles $(\mathrm{d}=2-3 \mathrm{~nm})$ is about $65 \mathrm{mV}$ lower vs. that for Pt black $(\mathrm{d}=10-20 \mathrm{~nm})$. Therefore, the surface coverage of $\mathrm{OH}_{\text {ad }}$ species on the Pt catalyst surface is higher for Pt nanoparticles as compared to larger Pt black particles. As a consequence, more active sites are blocked on a $\mathrm{Pt}$ nanoparticle catalyst surface and thus, $i_{\mathrm{k}}$ and $i_{\mathrm{k}, \mathrm{spec}}$ decreases. If the effect accounts for our sputtered electrodes, there should be a shift in the $\mathrm{OH}_{\mathrm{ad}}$ adsorption potential to more negative potentials values, when going from particular films (agglomerated particles) on the electrodes with high Pt loadings to isolated nanoparticles with an average diameter of $2 \mathrm{~nm}$ on electrodes with low Pt loadings. Using the peak maximum of the $\mathrm{OH}_{\text {ad }}$-desorption in the double layer corrected $\mathrm{CV}$ from Fig. 4 as an indicator of the desorption potential of $\mathrm{OH}_{\mathrm{ad}}$, a clear logarithmic correlation can be deduced, see Fig. 7a with the desorption peak maxima shifting to lower potential values by $22 \mathrm{mV}$ per decade. This indicates that changing the loading of the sputtered electrodes by two orders of magnitude, as we did in our study, an overall peak shift of $44 \mathrm{mV}$ occurs. This is qualitatively comparable to the value of $65 \mathrm{mV} /$ dec found in ref. [5] That is, for electrodes with low Pt loadings, which mostly contain Pt nanoparticles, more surface area is blocked by $\mathrm{OH}_{\text {ad }}$ then for those with high
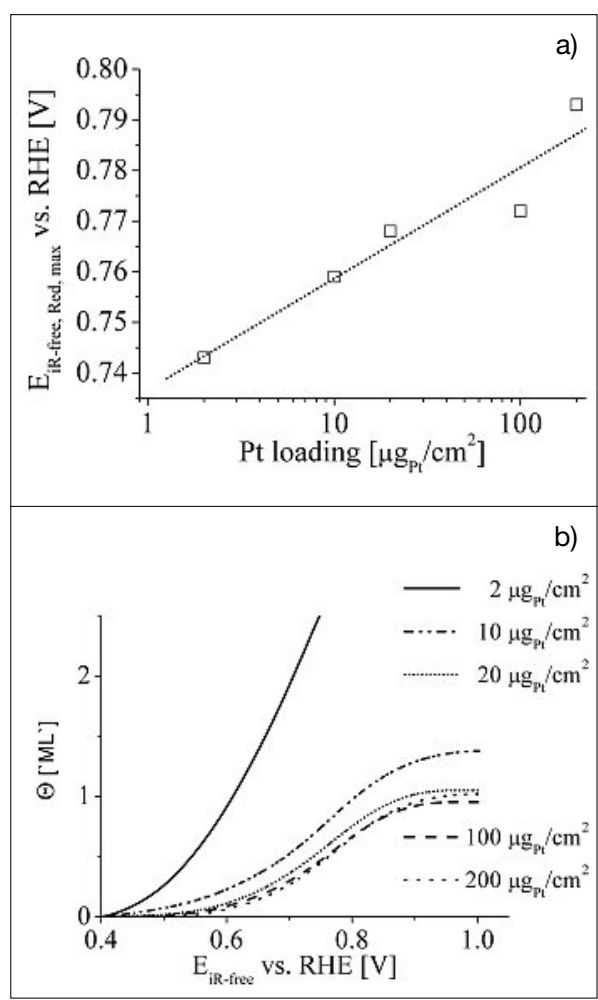

Fig. 7. a) Peak maxima of the $\mathrm{Pt}-\mathrm{OH}_{\mathrm{ad}}$ reduction peak determined for various loadings $\left(2-200 \mu g_{p t} / \mathrm{cm}^{2}\right)$. The maxima are derived from the CVs depicted in Fig. 4, after subtracting the double layer $\left(20-200 \mu \mathrm{g}_{\mathrm{pl}} / \mathrm{cm}^{2}\right)$ or the pure carbon CV $\left(2-10 \mu \mathrm{g}_{\mathrm{pt}} / \mathrm{cm}^{2}\right)$. b) $\mathrm{OH}$ coverage of the Pt catalyst surface area for various loadings, determined from the $\mathrm{PtOH}_{\text {ad }}$ reduction peaks depicted in Fig. 4.

Pt loadings, which mostly contain Pt agglomerates and films. The results suggest that for Pt loadings $>100 \mu \mathrm{g}_{\mathrm{pt}} / \mathrm{cm}^{2}$ the $\mathrm{Pt}$ agglomerates and films are comparable to Pt-black, following the $65 \mathrm{mV} / \mathrm{dec}$ voltage shift.

Assuming a single electron transfer for the formation of the oxygenated species on $\mathrm{Pt}\left(\mathrm{Pt}-\mathrm{OH}_{2}\right)$ the integration of the cathodic sweeps of the double layer corrected CVs in a potential range between $0.4 \mathrm{~V}$ and $1.0 \mathrm{~V}$, normalized to the specific charge of one monolayer $\mathrm{Pt}\left(0.210 \mathrm{mC} / \mathrm{cm}^{2}{ }_{\mathrm{Pt}}\right)$, the formal coverage of the oxygenated species can be calculated. The resulting surface coverage is plotted vs. the potential, starting with $0 \%$ of coverage at $0.4 \mathrm{~V}$, as shown in Fig. 7b. As expected, a clear qualitative trend of a decreasing $\mathrm{OH}_{\text {ad }}$ surface coverage can be observed with increasing Pt loading. As discussed by Mayerhofer et al. ${ }^{[76]}$ the potential of zero total charge (PZTC) on $\mathrm{Pt}$ nanoparticles is shifting negatively by $35 \mathrm{mV}$ with decreasing particle size from $30 \mathrm{~nm}$ to $1 \mathrm{~nm}$. This is in agreement with an earlier concept introduced by Frumkin, ${ }^{778]}$ who stated increased anion electrosorption properties with decreasing particle sizes. In other words, the smaller the Pt particles (or the larger the specific surface area) the more oxophilic the surface becomes. 


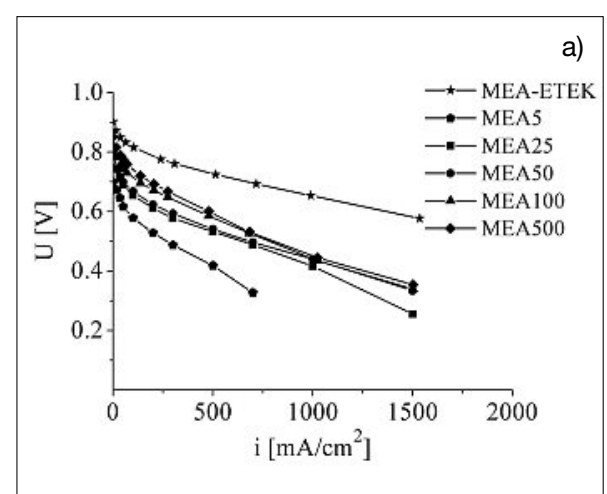

b)

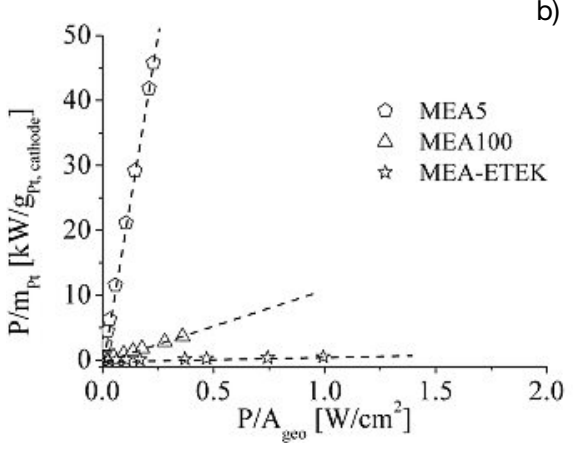

Fig. 8. a) iU-curves of MEAs with various $\mathrm{Pt}$ loadings of sputtered cathodes of $5-500 \mu \mathrm{g}_{\mathrm{pt}}$ ' $\mathrm{cm}^{2}$ compared to ETEK cathodes, measured for $\mathrm{H}_{2} / \mathrm{O}_{2}$ at $\mathrm{T}=80^{\circ} \mathrm{C}, 1 \mathrm{bar}, 100 \%$ R.H. and constant gas flow of $600 \mathrm{~mL} / \mathrm{min}$. b) Plot of the cathode Pt mass specific power density vs. geometric power density for various current densities of $0-0.3 \mathrm{~A} / \mathrm{cm}^{2}$.

The ORR on the electrodes with the different loadings appears to follow the identical reaction mechanisms (see e.g. the parallel Tafel plots in Fig. 5a), and the reaction rate is simply determined by the number of free surface sites (that means, the number of surface sites not covered by spectator species $\mathrm{OH}_{\mathrm{ad}}$ ), i.e. the current is proportional to $\left(1-\Theta_{\mathrm{OH}}^{\mathrm{ad}}\right)^{\mathrm{x}}$ with $\mathrm{x}$ being the reaction order of the adsorption/desorption process. ${ }^{[9,79]}$

In summary, it can be assumed that the different Pt particle sizes in the sputtered electrodes account for varying oxygen reduction kinetics. Electrodes with low $\mathrm{Pt}$ loadings, mostly containing $\mathrm{Pt}$ nanoparticles, show a high $\mathrm{OH}_{\text {ad }}$ surface coverage compared to electrodes with high Pt loadings, and mainly Pt agglomerate and film formation. As a consequence, the specific ORR activity for higher loadings increases with the reduction of the surface coverage of the spectator species $\mathrm{OH}_{\text {ad }}$.

\subsection{Fuel Cell Performance of Pt Catalysts in PEFCs}

More relevant for a possible technical application are measurements performed with sputtered cathodes in a PEFC. The resulting polarization curves for various Pt loadings are shown in Fig. 8a in comparison to a MEA with the ink-prepared cathode. Comparing MEA500 with MEAETEK at $0.65 \mathrm{~V}$, the MEA with the sputtered cathode show a reduced performance of about $68 \%$. Yet, a further decrease in $\mathrm{Pt}$ loading down to $100 \mu \mathrm{g}_{\mathrm{p}} / \mathrm{cm}^{2}$ (MEA100) results only in a loss of $73 \%$ compared to the MEA using the commercial cathode (MEA-ETEK). Only for loadings $<5 \mu \mathrm{g}_{\mathrm{p}}$ / $\mathrm{cm}^{2}$ a further significant performance decrease is observed (97\% of MEA-ETEK). The nonlinear performance reduction can be explained by the logarithmic dependence of Pt loading and ECSA, as shown before (Fig. 3). Thus, ECSA increases by a factor of five by increasing the loading from $5 \mu \mathrm{g}_{\mathrm{Pt}} / \mathrm{cm}^{2}$ to $100 \mu_{\mathrm{Pt}} / \mathrm{cm}^{2}$, but only by a factor of 1.6 for a further increase up to $500 \mu \mathrm{g}_{\mathrm{P}} / \mathrm{cm}^{2}$. ECSA for the latter loading is still a factor of 15 smaller then for MEA-ETEK, having the same Pt loading.

Although the performance of the sputtered cathodes is quite low compared to the ink base electrodes, our MEAs achieve reasonable voltages of around $0.4 \mathrm{~V}$ at high current densities of $1.5 \mathrm{~A} / \mathrm{cm}^{2}$ using pure oxygen. This value is high compared to most other sputtered systems; see Table 2, where we tried to summarize some of the recent findings from the literature. Besides the data reported from 3M Company with high current densities of up to $1.2 \mathrm{~A} / \mathrm{cm}^{2}$ at $60 \%$ R.H., all other reported data are similar or significantly lower than our results. The sputtered electrodes allow a low power density per geometric surface, but for small loadings of $5 \mu \mathrm{g}_{\mathrm{pt}} / \mathrm{cm}^{2}$ very high power densities per cathode Pt loading can be presented (Fig. 8b). In this calculation, the anode loading is not included, as it was demonstrated in our previous paper that the anode performance is uncritical, even with ultra-low Pt loadings. ${ }^{[6]}$ Despite the high mass specific power densities, for automobile applications a significant increase in performance must be achieved when using sputtered electrodes, e.g. by increasing ECSA due to sputtering on different substrates (e.g. demonstrated by $3 \mathrm{M}$ in their NSTF approach). Yet, for applications in the low power range, the sputtered electrodes are of interest from an economic point of view. The durability, however, still needs to be tested, but it can be assumed not to be a critical factor, if literature results obtained with electrodes showing extended Pt-black-type surfaces are considered. ${ }^{[4]}$

For comparison of results obtained with the sputtered cathode MEAs and the model electrodes measured in $0.1 \mathrm{M} \mathrm{HClO}_{4}$, the polarization curves have been iR-corrected, as described above (note, the currents are corrected for hydrogen crossover of $1 \mathrm{~mA} / \mathrm{cm}^{2}$ determined electrochemically in the driven-cell mode ${ }^{[80]}$ ). Mass-transport induced limitations have been neglected, due to the quasi differential gas flows

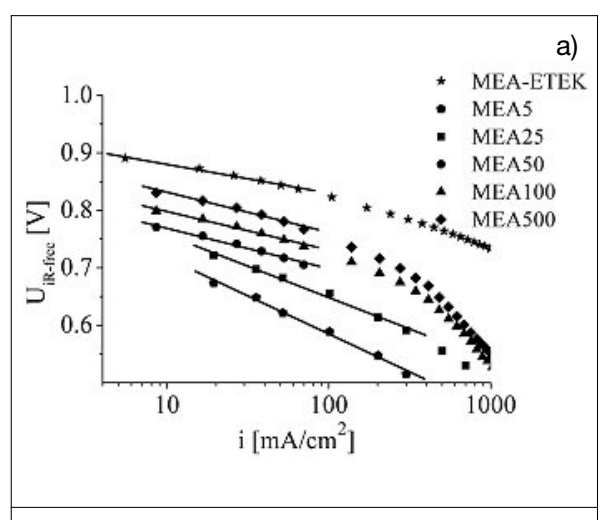

b)

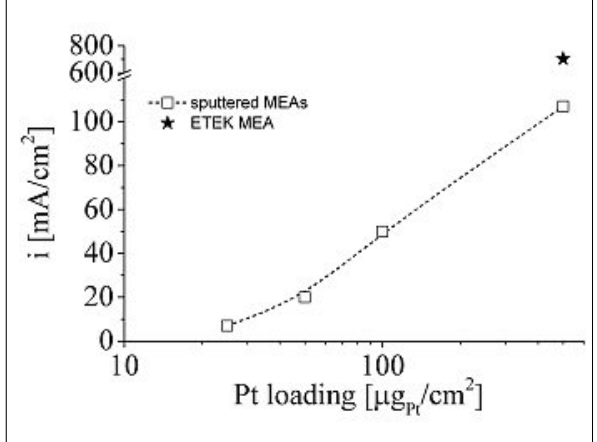

Fig. 9. a) IR corrected polarization curves of MEAs with various $\mathrm{Pt}$ loadings depicted from Fig. 8a. b) Comparison of the $\mathrm{O}_{2}$ reduction activity at $0.9 \mathrm{~V}$ of sputtered cathodes with different $\mathrm{Pt}$ loadings and ETEK cathode, measured for $\mathrm{H}_{2} / \mathrm{O}_{2}$ at $\mathrm{T}=80{ }^{\circ} \mathrm{C}, 1$ bar, $100 \%$ R.H., constant gas flow of $600 \mathrm{~mL} / \mathrm{min}$ and current density of $0.75 \mathrm{~A} / \mathrm{cm}^{2}$. The dotted line serves as guide to the eye.

and operation. The resulting Tafel plots are shown in Fig. 9a, representing a clear trend for the cathode kinetics at least at current densities below $100 \mathrm{~mA} / \mathrm{cm}^{2}$. At higher current densities, the change in the Tafel slope to higher values either represents induced mass transport issues even under the applied operation ${ }^{[81]}$ conditions or may point to a change in the potential dependent formation of oxygenated species, especially at low loadings, see $e . g$. the discussion in ref. [82,83]. Further studies in this direction need to be carried out in the future for complete understanding of this phenomenon.

The current densities $i$ are plotted for $\mathrm{U}_{\mathrm{iR} \text {-free }}=0.75 \mathrm{~V}$ against the Pt loading (Fig. 9b). A logarithmic increase of $i$ is observed, as expected from the results of the model electrode experiments. Also, the current density of the MEA with the commercial electrode (MEA-ETEK) was much higher as compared to the values for all other electrodes with varying Pt loadings. Again, this is due to the logarithmic growth of ECSA also seen for the sputtered PEFC cathodes (Fig. 3), as already discussed for the model electrodes. Furthermore, $i$ for MEA500 is about a factor 6.3 higher than for MEA25, but still a factor of 6.6 smaller than for MEA-ETEK. For MEA5, $i$ could not be 
Table 2. Summary of PEFC results obtained using electrodes (both anode and cathode) in which the catalyst layer is prepared by sputtering of Pt or Pt-alloys.

\section{Parameters for sputter deposition conditions}

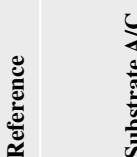

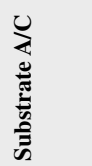

C: GDL

$38 \mathrm{~A} / \mathrm{C}$ multilayers on Nafion 115

uncat. E-TEK

39 uncat. E-TEK

uncat. E-TEK

39 uncat. E-TEK
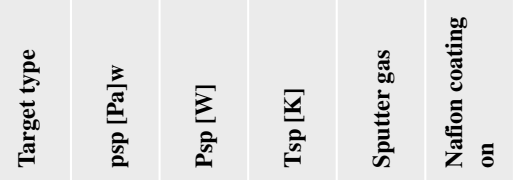

\begin{tabular}{l|l}
$\mathrm{Pt}$ & 0.5
\end{tabular}

\section{0 n.m.}

\begin{tabular}{l|l}
\hline Pt & 0.7
\end{tabular}

\begin{tabular}{l|l|l}
\hline & $30-50 \quad$ n.m. \\
\hline
\end{tabular}

$\mathrm{Pt}, \mathrm{Ru}$ n.m.

\begin{tabular}{|l|l|l|}
\hline Pt, Ru n.m. n.m. \\
\hline
\end{tabular}

\begin{tabular}{|l|l|l}
\hline Pt, Ru wwn. n.m. n. \\
\hline
\end{tabular}

Pt, Ru n.m.

42 A-6-P ELAT, E-TEK

\begin{tabular}{l|l}
$\mathrm{Pt}$ & 1.3
\end{tabular}

$3 \quad 50$

40 A/C: ELAT

41 A/C: Cr-monolayer on GDL (ELAT)

41 A/C: Cr-monolayer on GDL (ELAT)

41 A/C: Cr-monolayer on GDL (ELAT)

41 A/C: Cr-monolayer on GDL (ELAT)

Parameters for sputter deposition conditions
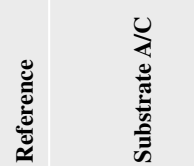

41 A/C: Cr-monolayer on GDL (ELAT)
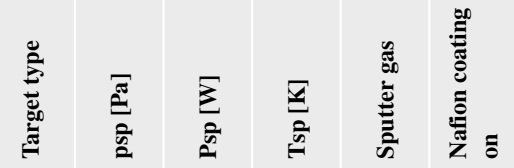

37 A/C: GDL (Toray)

37 A/C: ink-based MEA \begin{tabular}{|l|l|l|l|l|l|l|}
\hline Pt & 2 & 50 & 298 & n. m. & A/C & yes \\
\hline
\end{tabular}

\begin{tabular}{|l|l|l|l|l|l|l|}
\hline Pt & 2 & 50 & 298 & Ar & M & yes \\
\hline
\end{tabular}

\begin{tabular}{|l|l|l|l|l|l|l|}
\hline Pt & 2 & 50 & 298 & Ar & M & yes \\
\hline
\end{tabular}

$$
\begin{array}{|l|l|l|}
\hline 2 & 50 & 298 \\
\hline 2 & 50 & 298 \\
\hline
\end{array}
$$$$
\begin{array}{ll} 
\\
\mathrm{M}
\end{array}
$$$$
\text { A/C: multilayers } \quad P t=8.3=14,4 \text { m.m. }
$$$$
\text { on Nafion } 117
$$$$
24 \text { C: uncat. E-TEK }
$$ 


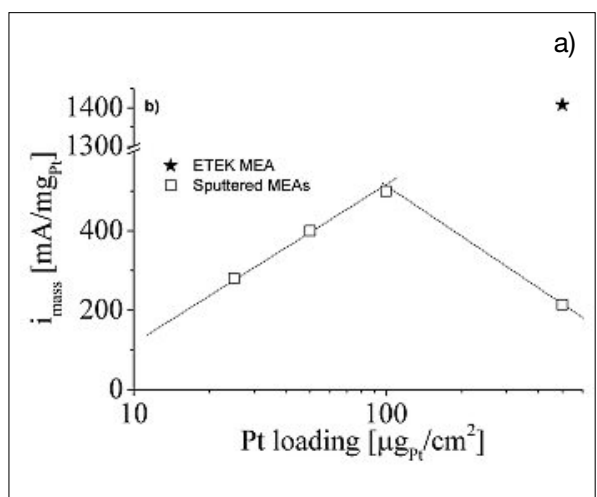

b)

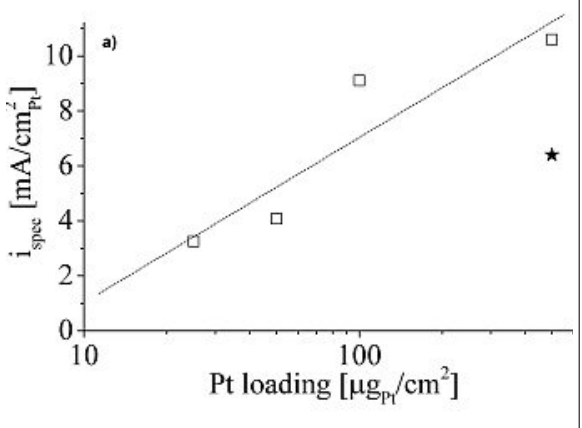

Fig. 10. Comparison of the $\mathrm{O}_{2}$ reduction a) mass specific pseudo activity $i_{\text {mass }}$ and b) surface specific pseudo activity $i_{\text {spec }}$ of sputtered cathodes with different $\mathrm{Pt}$ loadings compared to ETEK cathode, measured for $\mathrm{H}_{2} / \mathrm{O}_{2}$ at $\mathrm{T}=$ $80{ }^{\circ} \mathrm{C}, 1$ bar, $100 \%$ R.H., constant gas flow of $600 \mathrm{~mL} / \mathrm{min}$ and current density of $0.75 \mathrm{~A} / \mathrm{cm}^{2}$. The dotted lines serve as guide to the eye.

determined, as the open circuit potential of the MEAs was only around $700 \mathrm{mV}$.

The corresponding surface and mass specific activities $i_{\text {spec }}$ and $i_{\text {mass }}$, respectively, are shown in Fig. 10a and 10b. The values for $i_{\text {spec }}$ constantly increase with increasing loading. The specific surface area for the MEA500 is even higher than for MEA-ETEK. The reason for this increase may be found in the aforementioned effect of particle size, similarly discussed for the model electrodes. A proof, however, as in the case of the model electrodes is not possible, due to the low quality of the CVs measured in a PEFC with low Pt loadings. Yet, as TEM pictures have shown elsewhere, ${ }^{[6]}$ in electrodes with Pt loadings of $100 \mu \mathrm{g}_{\mathrm{Pt}} / \mathrm{cm}^{2}$ a dense film of Pt on the MPL carbon support material is formed, whereas electrodes $\leq 50 \mu \mathrm{g}_{\mathrm{Pt}} / \mathrm{cm}^{2}$ mainly show $\mathrm{Pt}$ nanoparticles. It is reasonable to transfer the picture gained from the model electrode experiments onto the PEFC experiments. Therefore, the excursive increase of $i_{\text {spec }}$ could be due to the change in catalyst morphology and the resulting particle size effect. The effect seems to be more distinct in the PEFC.

The particle size effect could also explain the behaviour of $i_{\text {mass }}$ (Fig. 10b). First, with increasing Pt loading $i_{\text {mass }}$ is increasing, which is explainable by the increase in specific Pt surface area until this point of discussion. As discussed before, higher loadings only lead to formation of a Pt film, i.e. every additional amount of $\mathrm{Pt}$ is basically buried inside the sputtered catalyst layers, resulting in a significant increase in $\mathrm{Pt}$ loading, but no increase of Pt surface area. This plot demonstrates the optimum Pt loading, for which the mass specific current density is maximized with optimized catalyst kinetics.

\subsection{Comparison of Sputtered Electrodes}

A summary of literature findings of sputtered PEFC electrodes is shown in Table 2, comparing Pt loading, fuel cell performance, sputter parameters and fuel cell testing conditions with each other. Due to a much higher surface area ECSA of the $3 \mathrm{M}$ electrode type, these show the highest PEFC performance. Yet, also the straightforward approach of sputtering Pt on an MPL shows reasonable performances at low Pt loadings, as compared to other sputtered electrodes investigated. In order to achieve a fairer comparison between the differently prepared electrodes, experimental parameters as temperature, pressure, and humidification in the fuel cell test must also be considered, making it difficult to compare the different results shown. It should be noted, however, that the very good performance values for $3 \mathrm{M}$ NSTF catalyst most likely is a result of the ca. 3fold increased specific surface area at similar loadings of $c a$. 100 to $150 \mu \mathrm{g} / \mathrm{cm}^{2}$. This in turn means that the critical process to create these highly active electrodes is the choice of the correct substrate material (e.g. the whiskers utilized by the $3 \mathrm{M}$ company and the texturing of the transferred layers) offering enough roughness to create a high specific Pt surface area.

Recently, we could demonstrate that applying ultra-low loaded sputtered electrodes as anodes in PEFCs, almost negligible performance loss could be achieved, due to the fast HOR. Therefore, a loss in ECSA on the anode side is not limiting the total fuel cell performance, as was demonstrated elsewhere. ${ }^{[6,84]}$ Having only sputtered anodes, current densities of $0.97 \mathrm{~A}$ / $\mathrm{cm}^{2}$ at voltages of $0.6 \mathrm{~V}$ can be achieved, similar to E-TEK fuel cell performance.

\section{Conclusion}

Sputtered Pt catalyst layers show many advantages as compared to electrodes with ink-derived catalyst layers using $\mathrm{Pt} / \mathrm{C}$ catalysts, e.g. ability to prepare thin Pt films, controlled loading, dry one step process, no use of ionomer, and carbon free support structures. One of the main challenges represents the low achievable electrochemical surface area ECSA, due to the low dispersion of the Pt electrocatalyst. This leads to lower activities of cathodes with sputtered Pt catalyst layers, compared to cathodes with $\mathrm{CL}$ based on $\mathrm{Pt} / \mathrm{C}$ containing inks, and thus to a lower fuel cell performance.

Although the specific activity is increased, utilizing extended Pt-black-type surfaces from the sputtered with respect to the ink-derived catalyst layers, respectively, this effect cannot compensate for the total performance loss due to the approximately 1-2 order of magnitude lower specific surface area.

The reason for the increase of specific activity was shown to be a result of increasing the particle sizes for sputtered catalyst layers literally forming Pt layers, which is leading to properties of Pt-black type rather than to a supported Pt catalyst, respectively. To overcome the challenge of low ECSA, both the Pt dispersion as well as the sputtered surface area should be increased as in the case of the 3M NSTF approach. Both ways will effectively increase the $\mathrm{Pt}$ utilization and consequently the cathode performance. As could be shown in this manuscript, the choice of the appropriate substrate material for application of the sputtered Pt catalyst layers is critical for well performing PEFCs.

\section{Acknowledgement}

We thank M. Döbeli (Ion Beam Physics, ETH Zürich) for RBS measurements. $H$. Schulenburg and A. Wokaun are greatly acknowledged for support and helpful discussions.

Received: January 20, 2012

[1] IPHE, 'International Partnership for Hydrogen and Fuel Cells in the Economy. Fuel Cell Cost Analysis Summary', http://www.iphe.net/ docs/Resources/IPHE\%20Fuel\%20Cell\%20 Cost\%20Comparison\%20Report.pdf, 2009.

[2] S. Satyapal, 'Fuel Cell System Cost - 2011;DOE Hydrogen Program Record', http://www. hydrogen.energy.gov/pdfs/11012_fuel_cell_ system_cost.pdf, 2011.

[3] C. H. Hsu, C. C. Wan, J. Power Sources 2003 , 115, 268.

[4] M. K. Debe, A. K. Schmoeckel, G. D Vernstrorn, R. Atanasoski, J. Power Sources 2006, 161, 1002 .

[5] H. A. Gasteiger, S. S. Kocha, B. Sompalli, F. T. Wagner, Appl. Catal. B: Environ. 2005, 56, 9.

[6] B. Schwanitz, H. Schulenburg, M. Horisberger, A. Wokaun, G. G. Scherer, Electrocatalysis 2011, 2, 35 .

[7] W. C. Sheng, H. A. Gasteiger, Y. Shao-Horn, $J$ Electrochem. Soc. 2010, 157, B1529.

[8] T. J. Schmidt, N. M. Markovic, 'Electrocatalysis of Inorganic Reactions: Pure Pt Surfaces', in 'Encyclopedia of Surface and Colloid Science', Ed. P. Somasundaran, Taylor and Francis: New York, 2006, pp 2032-2047.

[9] N. M. Markovic, T. J. Schmidt, V. Stamenkovic, P. N. Ross, Fuel Cells 2001, 1, 105.

[10] 'Polymer Electrolyte Fuel Cells 10 - ECS Transactions 33(1)', Eds. H. A. Gasteiger, H. Uchida, V. Ramani, A. Weber, T. J. Schmidt, T. F. Fuller, P. Strasser, P. Shirvanian, M. Inaba, 
M. Edmundson, F. N. Buechi, D. J. Jones, C. Lamy, R. Mantz, S. Narayanan, R. M. Darling, T. Zawodzinski, The Electrochemical Society: Pennington, NJ, 2010.

[11] 'Polymer Electrolyte Fuel Cells 11 - ECS Transactions 41(1)', Eds. H. A. Gasteiger, F. N. Buechi, V. Ramani, A. Weber, P. Shirvanian, T. F. Fuller, S. Narayanan, H. Nakagawa, M Edmundson, D. J. Jones, H. Uchida, C. Lamy, P. Strasser, S. Mukerjee, R. Mantz, K. SwiderLyons, T. J. Schmidt, The Electrochemical Society: Pennington, NJ, 2011

[12] P. Pugazhendhi, M. Raja, G. Sasikumar, P. Sridhar, Bull. Electrochem. 1999, 15, 353.

[13] G. Sasikumar, J. W. Ihm, H. Ryu, Electrochim. Acta 2004, 50, 601.

[14] M. S. Wilson, S. Gottesfeld, J. Electrochem. Soc. 1992, 139, L28.

[15] E. A. Ticianelli, J. G. Beery, S. Srinivasan, $J$. Appl. Electrochem. 1991, 21, 597.

[16] L. H. S. Gasparotto, E. G. Ciapina, E. A. Ticianelli, G. Tremiliosi, J. Power Sources 2012, 197, 97.

[17] M. W. Verbrugge, J. Electrochem. Soc. 1994, $141,46$.

[18] A. F. Gulla, M. S. Saha, R. J. Allen, S. Mukerjee, Electrochem. Solid State Lett. 2005, 8, A504.

[19] M. S. Saha, A. F. Gulla, R. J. Allen, S. Mukerjee, Electrochim. Acta 2006, 51, 4680.

[20] A. F. Gulla, M. S. Saha, R. J. Allen, S. Mukerjee, J. Electrochem. Soc. 2006, 153, A366.

[21] K. Sasaki, J. X. Wang, M. Balasubramanian, J. McBreen, F. Uribe, R. R. Adzic, Electrochim. Acta 2004, 49, 3873

[22] K. Yamada, K. Miyazaki, S. Koji, Y. Okumura, M. Shibata, J. Power Sources 2008, 180, 181.

[23] R. O'Hayre, S. J. Lee, S. W. Cha, F. B. Prinz, J. Power Sources 2002, 109, 483.

[24] S. Hirano, J. Kim, S. Srinivasan, Electrochim. Acta 1997, 42, 1587.

[25] P. Brault, A. Caillard, A. L. Thomann, J. Mathias, C. Charles, R. W. Boswell, S Escribano, J. Durand, T. Sauvage, J. Phys. D-Appl. Phys. 2004, 37, 3419.

[26] A. Caillard, P. Brault, J. Mathias, C. Charles, R. W. Boswell, T. Sauvage, Surf. Coatings Technol. 2005, 200, 391.

[27] P. Brault, S. Roualdes, A. Caillard, A. L. Thomann, J. Mathias, J. Durand, C. Coutanceau, J. M. Leger, C. Charles, R. Boswell, Eur. Phys. J.-Appl. Phys. 2006, 34, 151.

[28] P. Brault, A. Caillard, A.-L. Thomann, Chem. Vapor Deposition 2011, 17, 296.

[29] M. Mougenot, A. Caillard, P. Brault, S Baranton, C. Coutanceau, Int. J. Hydrogen Energy 2011, 36, 8429.

[30] K. L. Huang, Y. C. Lai, C. H. Tsai, J. Power Sources 2006, 156, 224.

[31] M. Alvisi, G. Galtieri, L. Giorgi, R. Giorgi, E. Serra, M. A. Signore, Surf. Coatings Technol. 2005, 200, 1325 .

[32] C. H. Wan, M. T. Lin, Q. H. Zhuang, C. H. Lin, Surf. Coatings Technol. 2006, 201, 214.

[33] K. Makino, K. Furukawa, K. Okajima, M. Sudoh, Electrochim. Acta 2005, 51, 961.

[34] K. Makino, K. Furukawa, K. Kajima, M. Sudoh, J. Power Sources 2007, 166, 30.

[35] C. K. Witham, W. Chun, T. I. Valdez, S. R. Narayanan, Electrochem. Solid State Lett. 2000, 3,497 .

[36] A. T. Haug, R. E. White, J. W. Weidner, W. Huang, S. Shi, N. Rana, S. Grunow, T. C.
Stoner, A. E. Kaloyeros, J. Electrochem. Soc. 2002, 149, A868.

[37] A. T. Haug, R. E. White, J. W. Weidner, W. Huang, S. Shi, T. Stoner, N. Rana, J. Electrochem. Soc. 2002, 149, A280.

[38] S. Y. Cha, W. M. Lee, J. Electrochem. Soc. 1999, 146, 4055.

[39] C. L. Chang, T. C. Chang, W. Y. Ho, J. J. Hwang, D. Y. Wang, Surf. Coatings Technol. 2006, 201, 4442.

[40] D. Gruber, J. Muller, J. Power Sources 2007, 171, 294.

[41] D. Gruber, N. Ponath, J. Muller, Electrochim. Acta 2005, 51, 701 .

[42] Y. H. Cho, S. J. Yoo, Y. H. Cho, H. S. Park, I. S. Park, J. K. Lee, Y. E. Sung, Electrochim. Acta 2008, 53, 6111 .

[43] T. Nakakubo, M. Shibata, K. Yasuda, J. Electrochem. Soc. 2005, 152, A2316.

[44] H. Rabat, P. Brault, Fuel Cells 2008, 8, 81.

[45] Y. K. Xiu, N. Nakagawa, J. Electrochem. Soc. 2004, 151, A1483.

[46] P. K. Sinha, W. B. Gu, A. Kongkanand, E. Thompson, J. Electrochem. Soc. 2011, 158, B831.

[47] M. Secanell, K. Karan, A. Suleman, N. Djilali, J. Electrochem. Soc. 2008, 155, B125.

[48] B. Andreaus, M. Eikerling, in 'Device and Materials Modeling in PEM Fuel Cells', Eds. S. J. Paddison, K. S. Promislov, Springer Science+Business Media, LLC.: New York, 2009.

[49] M. K. Debe, S. M. Hendricks, G. D. Vernstrom, J. Willey, M. Hamden, C. K. Mittelstaedt, C. B. Capuano, K. E. Ayers, E. Anderson, Meeting Abstracts 220th ECS Meeting Boston 2011, 2011, Abstract 694.

[50] P. T. Yu, W. Gu, J. Zhang, M. Makharia, F. T. Wagner, H. A. Gasteiger, 'Carbon Support Requirements for Highly Durable Fuel Cell Operation', in 'Polymer Electrolyte Fuel Cell Durability', Eds. F. N. Büchi, M. Inaba, T. J. Schmidt, Springer Science and Business Media: New York, 2009, pp. 29-53.

[51] F. T. Wagner, S. G. Yan, P. T. Yu, 'Catalyst and Catalyst-Support Durability', in 'Handbook of Fuel Cells - Fundamentals, Technology and Applications', volume 5, 'Advances in Electrocatalysis, Materials, Diagnostics and Durability', Eds. W. Vielstich, H. Yokokawa, H. A. Gasteiger, John Wiley \& Sons, Chichester, 2009, pp 250-263.

[52] N. Linse, G. G. Scherer, A. Wokaun, L. Gubler, 'Start/Stop Induced Carbon Corrosion in Polymer Electrolyte Fuel Cells', in Proceedings of the Asme 8th International Conference on Fuel Cell Science, Engineering, and Technology 2010, Vol 2, 2010, pp 357-362.

[53] H. Schulenburg, B. Schwanitz, N. Linse, G. G. Scherer, A. Wokaun, J. Krbanjevic, R. Grothausmann, I. Manke, J. Phys. Chem. C 2011, 115, 14236

[54] U. A. Paulus, Z. Veziridis, B. Schnyder, M. Kuhnke, G. G. Scherer, A. Wokaun, J. Electroanal. Chem. 2003, 541, 77.

[55] B. Schwanitz, PhD Thesis No. 20142, ETH Zürich, 2012

[56] D. A. Blom, J. R. Dunlap, T. A. Nolan, L. F. Allard, J. Electrochem. Soc. 2003, 150, A414.

[57] C. Hartnig, T. J. Schmidt, J. Power Sources 2011, 196, 5564.

[58] H. Schulenburg, B. Schwanitz, J. Krbanjevic,
N. Linse, G. n. G. Scherer, A. Wokaun. Electrochem. Commun. 2011, 13, 921.

[59] L. Gancs, T. Kobayashi, M. K. Debe, R. Atanasoski, A. Wieckowski, Chem. Mater. 2008, 20, 2444.

[60] A. Kongkanand, Z. Y. Liu, I. Dutta, F. T. Wagner, J. Electrochem. Soc. 2011, 158, B1286.

[61] I. Takahashi, S. S. Kocha, J. Power Sources 2010, 195, 6312 .

[62] A. Bonakdarpur, K. Stevens, G. D. Vernstrom, R. Atanasoski, A. K. Schmoeckel, M. K. Debe, J. Dahn, Electrochim. Acta 2007, 53, 688

[63] T. J. Schmidt, H. A. Gasteiger, G. D. Stäb, P. M. Urban, D. M. Kolb, R. J. Behm, J. Electrochem. Soc. 1998, 145, 2354.

[64] U. A. Paulus, T. J. Schmidt, H. A. Gasteiger, R J. Behm, J. Electroanal. Chem. 2001, 495, 134.

[65] T. J. Schmidt, H. A. Gasteiger, W. Vielstich, H. A. Gasteiger, A. Lamm, 'Rotating Thin-Film Method for Supported Catalysts', in 'Handbook of Fuel Cells: Fundamental, Technology, and Applications', vol. 2, 'Electrocatalysis', John Wiley \& Sons, Chichester, 2003, pp 316-333.

[66] A. J. Bard, L. R. Faulkner, 'Electrochemical Methods', John Wiley \& Sons, New York, 1980.

[67] N. M. Markovic, H. A. Gasteiger, P. N. Ross, J. Phys. Chem. 1995, 99, 3411.

[68] B. N. Grgur, N. M. Markovic, P. N. Ross Jr., Can. J. Chem. 1997, 75, 1465.

[69] A. Damjanovic, D. B. Sepa, Electrochim. Acta 1990, 35, 1157.

[70] J. Bett, J. Lundquist, Electrochim. Acta 1973 18,343

[71] U. A. Paulus, A. Wokaun, G. G. Scherer, T. J Schmidt, V. Stamenkovic, N. M. Markovic, P. N. Ross Jr., J. Phys. Chem. B 2002, 106, 4181.

[72] U. A. Paulus, G. G. Scherer, A. Wokaun, T. J. Schmidt, V. Stamenkovic, N. M. Markovic, P. N. Ross Jr., Electrochim. Acta 2002, 47, 3787.

[73] A. Parthasarathy, S. Srinivasan, A. J. Appleby, C. R. Martin, J. Electrochem. Soc. 1992, 139, 2530.

[74] P. D. Beattie, V. I. Basura, S. Holdcroft, J. Electroanal. Chem. 1999, 468, 180.

[75] S. Mukerjee, S. Srinivasan, A. J. Appleby, Electrochim. Acta 1993, 38, 1661.

[76] K. J. J. Mayrhofer, B. B. Blizanac, M. Arenz, V. Stamenkovic, P. N. Ross, N. M. Markovic, J. Phys. Chem. B 2005, 109, 14433.

[77] H. A. Gasteiger, N. M. Markovic, Science 2009, 324, 48.

[78] A. N. Frumkin, O. A. Petrii, B. B. Damaskin, in 'Comprehensive Treatise in Electrochemistry', Plenum Press, New York, 1980.

[79] T. J. Schmidt, V. Stamenkovic, P. N. Ross Jr., N. M. Markovic, Phys. Chem. Chem. Phys. 2003, 5, 400 .

[80] S. S. Kocha, 'Principles of MEA preparation for PEM fuel cells', in 'Handbook of Fuel Cells. From Fundamentals to Applications', Eds. W. Vielstich, H. A. Gasteiger, A. Lamm, John Wiley \& Sons: Chichester, 2003, Vol. 3; pp 534.

[81] I. A. Schneider, M. H. Bayer, S. von Dahlen, J. Electrochem. Soc. 2011, 158, B343.

[82] N. P. Subramanian, T. A. Greszler, J. Zhang, W. Gu, R. R. Makharia, ECS Trans. 2012, 41, 985.

[83] Y. Huang, J. Zhang, Y. Liu, N. P. Subramanian, F. T. Wagner, J. Jorne, J. C. M. Li, ECS Trans. 2011, 41, 1009.

[84] A. Caillard, C. Charles, D. Ramdutt, R. Boswell, P. Brault, J. Phys. D-Appl. Phys. 2009, 42, 045207, DOI: $10.1088(0022-3727 / 42 / 045207$. 